FACTA UNIVERSITATIS

Series: Visual Arts and Music Vol. 7, No 1, 2021, pp. 23-40

https://doi.org/10.22190/FUVAM2101023D

Original scientific paper

\title{
THEATRE MANAGEMENT INVESTIGATION OF FEMALE PROMISCUITY: PREGNANCY AND ABORTION IMPACT ON UNIVERSITY EDUCATIONAL THEATRES IN NIGERIA
}

\author{
UDC 792.02:791.635-051-055.2 (669.1)
}

\section{Vincent O. Diakpomrere}

University of Benin, Faculty of Arts, Nigeria

\begin{abstract}
This study investigates promiscuity impacts, pregnancy impacts and abortion impacts of female undergraduates on management of the University of Benin educational theatre program, with implications on general theatre practice including Muson and Nollywood, in Nigeria. There are widespread speculations that female undergraduate theatre students are promiscuous and therefore highly prone to pregnancies and abortions for reasons or factors not confirmed by research. At least no such specific extensive study has been carried out in the University of Benin Theatre on this topic. Yet many female students are branded and treated merely as 'debased females and prospective prostitutes', and do not enjoy the goodwill, support, respect and honor their counterparts in the social, basic and environmental sciences as well as other fields of academic studies enjoy. This would be tantamount to a great disservice and injustice that need to be urgently addressed if a rigorous academic inquiry proves otherwise. Not to mention the undiscovered negative impacts the problem may have had, or currently be having on the training and practice of theatre arts in Nigeria: hence this investigation. The methodology, the subjects of study and study sample were carefully and systematically determined. The findings are mostly positive regarding the negative behavior investigated. Hence the recommendations point to measures aimed at checking and restricting these vices as well as their impact to a minimum as well as towards improving the moral, academic and managerial framework of educational theatre programs in Nigeria.
\end{abstract}

Key words: Female Promiscuity, Pregnancy, Abortion, Theatre Management, University Educational Theatre.

\footnotetext{
Received April 10, 2021/ Accepted June 2, 2021

Corresponding author: Vincent O. Diakpomrere

University of Benin, Faculty of Arts

PMB. 1154, Ugbowo, Benin City, Nigeria

E-mail: vindee333@yahoo.com 


\section{INTRODUCTION}

One of the negative expressions of Nigeria's status of an underdeveloped country is the tendency to classify and arrogate negative profiles and stereotypes to specific people without demonstrable causes or reliable underlying evidence. The practice of undue or unproven generalization dates back several centuries and is perhaps as old as man. Plato in 'The Republics' speaks of banning artists whom he alleged as being removed from originality by being imitators of reality from his ideal republic more out of sentimental inclination than persuasive conviction. Nigerian youths have recently been branded and consequently stigmatized as idle, lazy and unproductive by their head of state himself. Despite that the state has not offered the majority of them any meaningful or tangible 'building blocks or bricks' to build their lives with. Moreover, the actual narrative is that Nigerian youths in particular and Nigerians generally are robustly and naturally endowed with ample doses of creative and constructive ingenuity which they have glaringly demonstrated within Nigeria and other similar countries.

Figuratively or metaphorically, Nigerian youths are able to make 'bricks without straws', and have in the face of severe and blighting limitations, managed unwittingly, to build themselves and ascend to rare and unimaginable heights that fatuous and ignoble minds cannot appreciate or fathom. With regard to unsupported generalizations, people of the Urhobo tribe in south-south Nigeria are commonly called 'Urhobo-wayo', meaning 'Urhobo tricksters', whereas many innocent people of the tribe toil and thrive in honesty. Similarly, their sister tribe, the isokos are commonly called, 'isoko- tolopias', meaning violent people even if many innocent people of the tribe are nonbelligerent and peaceable. In quite the same presumptuous and unproven manner, the yorubas are generally and indiscriminately associated with being diabolic or fetish, the hausas are mentally or academically retarded, the people of kogi state with being heinously wicked and unforgiving, the ibos with being sexually low-slung, the venue men with gratifying hospitality of their wives, and so forth, without evincing any proof.

In particular, allusions of generalization made with respect to female theatre undergraduate or even post graduate students are intensely discrediting and downgrading. To begin with, the discipline of theatre arts is widely regarded in Nigeria as 'jumpology', a derogatory terminology that relegates the study of theatre arts to a mere brainless, brawny, physical and practical exercise lacking in intellectual and philosophic-theoretical fecundity. Therefore they are suitable for less cognitively developed and less intelligent, unserious, unstable and unfocussed persons. This point is articulated succinctly by Ayakoromo $(2015,9)$ in the following way:

"The theatre has become an interesting area of study in Nigeria, due largely to developments in the film industry, popularly called Nollywood. The profession was previously seen as a useless pastime, fit for college dropouts, loose girls and failures in life. The general opinion was that it was a waste of valuable time and resources to study the course at university level. Parents could not come to terms with the idea of their children, especially female children, (an emphasis or addition which is mine and is demonstrated subsequently below with late chief Hubert Ogunde's exemplary experience) going to "learn how to sing and dance".

The above clearly shows how the profession, vocation or career in theatre arts was regarded, derided and relegated, prior to the emergence and prolific developments in Nollywood. Moreover, theatre girls in particular are assumed or regarded as loose and 
wayward girls without deep moral values or virtues by character and nature. They are, as far as the society is concerned, practically and constantly exposed to compelling love situations through predominantly love plots like Shakespeare's Romeo and Juliet, by which whatever crumbs or remnants of moral fiber they were left with fly away in the heat of strong erotic winds of desire and uncontrollable passion. These uncanny images about ladies of the theatre profession are fuelled inadvertently by plays in which they smoke, wear bold make-up, dress provocatively, make love or kiss with multiple partners, and so forth. As a matter of fact, they are only truly playing their roles realistically. As stated above, female children were more particularly affected by this negative stereotyping of the theatre artist as inevitably or potentially loose or wayward. This phenomenon was so serious that the late Hubert Ogunde, extensively acclaimed as the veteran father of Nigeria's modern performance arts was compelled, that is, forced into marrying all the female artists in his troupe in order to imbue or invest them with a measure of dignity and self-respect (Clark 1980, 3). Clark proceeded to explain this phenomenon as follows:

"In 1945 Nigeria, his act was a courageous one. The actor or any person connected with the theatre was regarded as an `alarinjo', a name which Prof. J. A. Adedeji says 'originated as an abuse and which more or less picks them out and labels them as "rogues, vagabonds and sturdy beggars". It was therefore unusual for a man with a steady income as a police constable to throw up his job and join the rank of beggars. Initially he was jeered at. But as the Daily Comet put it, 'he had an idea, he had ambition, and he was prepared to sacrifice the immediate security of the policeman's poor pay for the uncertainty of the future. It was a big gamble"'.

Indeed not until quite recently, precisely since the advent of the Nollywood watershed, getting involved or venturing into theatre business was regarded as being for people with no future ambition (NFA) in Nigeria. This is the singular reason why Ogunde is considered and remains the supreme artist and father figure of contemporary Yoruba theatre (Clark 1980, 5) in particular, and modern theatre management and practice in general.

The gravity of the stereotyping and other negative public attitudes toward especially female artists is thus obviously a very serious area of hazard for theatre ladies. That is even speculated to affect their marrying and keeping their marriages and is certainly and unfortunately without adequate compensation on the Nigerian scene.

Furthermore, following the image presented above about females, especially girls, an image which is indiscriminately and inadvertently extended to girls studying theatre arts, male lecturers in such departments and programs are not spared. They are deemed derogatorily to be 'enjoying' themselves with an ample supply of virtue-less females whom they are assumed to be training in sophisticated arts of kissing, necking, smooching, osculating and general 'bedmatics'. The male colleagues of this breed of female undergraduates are equally not exempted. They are the 'lieutenants' who very ably assist the lecturers and are actually with their female counterparts almost round the clock in lecture rooms, in the library, hostel, diner, greenroom, rehearsal, stage and everywhere else they can be together, and are thus even more guilty. In addition, there are other presumed sets of 'customers or patrons' for the theatre girls in the various male categories of senior and junior non-academic staffs, as well as a prodigious set of males in the immediate and distant communities around the department and university. With an 'affluence' of 'male-materials' supply as allegedly provided bountifully and plenteously above, female promiscuity, pregnancies and abortions are speculated to be soaring, especially under the current hardships posed by COVID 19 and economic meltdown. 
Thereby some urgency for this research is imposed in order to get a clear picture of how things stand.

Naturally, if there are elements of truth and validity in these speculations regarding female undergraduate theatre students, then there is an urgent need to examine the challenges and risks the students are exposed to. What are the underlying causes of pregnancy for instance? Is it due to lack of reproductive health knowledge? Is it careless disregard or are the girls culturally or religiously compelled against the use of contraceptives and prevention aids such as condoms, coils, etc.? In case of pregnancy, how do the students deal with the problem? Are there adequate guidance and counseling facilities that students can consult for proper guidance on what to do so as not to complicate the situation? When abortions become pertinent, are the students apprehensive and repressed by considerations of the illegality of abortion laws in Nigeria into seeking clandestine and unorthodox options? Who do they meet, or can they consult for guidance in the situation they find themselves? How do they deal with the stigma of post abortion and the impacts upon continuing their education or programs, or does abortion summarily signify the termination of the educational aspirations or pursuits of such students? If that is the case, is it justified that a female student who engaged in a sexual act with a male counterpart has her career disrupted, or her life jeopardized while her male counterpart who probably instigated the action, just moves on with his life? Can laws, ordinances or statutes requiring males who impregnate females in the process of acquiring educational training to have the same fate as them, or made to pay compensation adequate to the consequences and impacts of the pregnancy upon the females be promulgated/instituted in order to check this menace and possibly alleviate it? What faith awaits the female in the future in an underdeveloped society like Nigeria as victims of untimely pregnancy and abortion? Can such girls/ladies still live normal lives and make the natural quota of their contributions as mothers, wives, citizens, career or professional women, future leaders, etc.? Are their lives twisted or truncated ultimately? These are some of the concerns and interests meant at checking the aforementioned vices as well as enhancing female/general educational theatre management training in Nigeria. These are issues we plan to explore in this study.

This study is therefore meant to confirm or deny the widespread view that many Nigerian female university undergraduates have unwanted pregnancies due to a high level of promiscuity, which leads to abortions and frequent severe unforeseen and avoidable complications which are sometimes fatal or cause terminal disabling conditions. For many female undergraduates (perhaps ignorant of its unpredictable and dangerous risks), abortion is the default preferred discernible panacea to dealing with unplanned and unwelcome pregnancy (as portended in studies by Akre C. et al. 2013, on reproductive health of sexual adolescents, with regards to consensual and non-consensual sex vis a viz their implications). This investigation is thus aimed at understanding the causes, factors or reasons behind the seemingly increasing female undergraduate promiscuity, increasing cases of pregnancies and increasing cases of abortions and consequent or concomitant scourges. The goal of the study is to ascertain the actual state of moral uprightness or depravity of female undergraduate students involved in academic theatre management training, as well as exposure to, levels and impacts of pregnancy and abortions. The study is expected to generate knowledge that will enlighten female university undergraduates, especially those involved in theatre management, as well as humanity, that being promiscuous is immoral, that immorality in general debases womanhood, that debased womanhood produces debased and degenerated human species or people, and this ultimately breeds a debased and retarded society epitomized 
by predominantly underdeveloped structures and entities. The study's significance is predicated on the injunction that high social ethics, moral values, and standards of discipline are inevitable pillars for building a sound, noble, virile, egalitarian, democratic and development-driven technological society, with a dynamic and sophisticated human capacity. Significantly and worth noticing reduction or eradication of the triple heinous vices of promiscuity (prostitution), pregnancy and abortion with their negative impacts upon any meaningful and progressive human institution, will undoubtedly enhance standards and performance in theatre management training in particular and theatre practice in Nigeria.

\section{Meaning And Brief Evolutionary Perspective of Theatre Management IN NIGERIA}

Briefly, the origins of professional theatre management in Nigeria up to the present time, including the moral impacts of female participation, especially since theatre management courses were introduced into the curriculum of the University of Ibadan, which has proliferated across theatre arts programs in Nigeria, shall be examined. According to Yemi Ogunbiyi, "the specific origins of Nigerian theatre and drama are speculative". The same however does not apply to the specific origins of theatre management in Nigeria. Theatre management in Nigeria was incepted in the traditional Alarinjo itinerant Yoruba theatre as "its development and rise were closely associated with Yoruba political and social history" (Ogunbiyi, 1981, 226). More specifically, according to Ogunbiyi, the roots of theatre management lie in the efforts of the various lineages that strove to outdo one another in excellence and innovative performance of each lineages' masquerade dance display, during the all souls annual festival organized during the reign of Sango as Alafin of Oyo. It was marked by 1700 as "the birth/inauguration of professional Yoruba theatre" (Ibid., 6). Ogunbiyi goes further to identify/classify three distinct periods and forms in the evolution/development of theatre management art/practice in Nigeria. The first is the traditional era, the second is the modern era, while the third is the post-modern era widely regarded as the literary theatre era. Elaborating on the era of traditional theatre management in Nigeria, Ogunbiyi identifies three clear phases: the dramatic ritual period in which the focus/content of performances was mainly traditional festivals held in honor of cult or ancestral heroes "The dramatic rituals performed usually embodied patently discernible drama and other serious masquerade plays" (Ibid., 10). The second category encompasses the popular tradition theatre period in which the focus was on arts intended to be popular by receiving public liking and support of the common people and projected "a place, a time, an audience and the performer as the major elements of a performance intended to give pleasure and joy and thus become popular" (Ibid., 10). The 3rd and last was the professional theatre management stage which featured the Alarinjo travelling theatre under the astute management of Hubert Ogunde (formerly regarded as the progenitor of modern professional Nigerian theatre management), as well as the theatre of late Kola Ogunmola, Duro Ladipo and the hundred and more of such new groups formed during that early period.

As for the modern theatre management period which is the middle period between the traditional period and the literary period, Yemi Ogunbiyi, Ebun Clark and others ascribe it to events which began by 1863, when the colonial British CMS established a broad policy aimed at Christianizing, Commercializing and Civilizing (CCC) Lagos, (Nigeria). Thus by 1866 , a top cream of elites comprising a body of Nigerian immigrants of freed 
slaves from Sierra Leone who were later in the year joined by Brazilian emigrants established a need for modern western recreational entertainment in Lagos. These elites included people like Bishop Ajayi Crowther, Otunba-Payne, Robert Campbell, Charles Foresythe, J.P. Davies, to mention but a few, who on the 24th of October, 1866 opened "The Academy", as it was then called, "as a social and cultural Centre for public enlightenment, dedicated to the promotion of the arts, science and culture". This singular august event became the platform and cornerstone of a watershed of social, artistic and cultural events that formed the fulcrum of the modern theatre management era in Lagos, with some corroborating structural and thematic responses from the Ibadan hemisphere. According to Ogunbiyi (Ibid), between 1866 and 1910, several groups, after the fashion of "The Academy", were founded, dedicated in one way or the other to the promotion of culture and the arts. Some prominent examples include: The Philharmonic Society (founded by Otunba-Payne in 1873), The Orpheus Club (founded also by Otunba-Payne in 1883), and the Brazilian Dramatic Company (founded about 1903 under the management of Patterson Zochoni da Silva), The Annual Coker Concerts (organized by Robert A. Coker) and The Mozart of West Africa), to mention just a few, all of which were thriving popular western and local cultural entertainment centers in "Victorian Lagos" due to application of sound business and theatre management skills. Hubert Ogunde, the doyen and master buster of Nigeria's modern theatre practice and management, dished his job with the Nigerian Police force, broke out from the auspice of the Church, went professional and took/held the horns of this new phenomenon, straddling this bubbling and broiling artistic broth as a fluid artistic medium, like a colossus, and drove this massive artistic stratagem to the apogee. By Ogunde prodigiously and the additive groups artistic splendor and acumen, Lagos became a shining-glowing light and leading city of quintessential, neverfailing artistic and cultural entertainment with a dynamic repertory that left its avid audience in endless throws of rapturous enchantments. Many of the great artistic products of this era are quite extant, though they are not quite accessible and popular today due to a fickle contemporary artistic appetite and inclination for past legacies and relics worsened by a conflagrating passion and proclivity of and for foreign cultural "superiority" and "domination".

As for the beginning of the literary theatre management tradition in Nigeria, Ogunbiyi ascribes it to "the literary plays that have been written since Ene Henshaw's This is our Chance (1956), while not excluding those, if any, that were written prior to 1956" (Ibid., 11). This author views the activities of the School of Drama of the newly established University of Ibadan (1955), which led to the introduction of a course titled Theatre Management as the foundation of the literary and professional theatre management training and practice in Nigeria. Everything that came and went before this crucial development is part of the traditional and modern eras, which held sway and paved the way for this landmark development in the annals of Nigeria's artistic and cultural expedition. The establishment of the school of drama and the provision of astute and visionary leadership through the human instrument of Geoffrey Axworthy, a Briton who actively and dedicatedly inspired and kept a number of artistic and cultural canons roasting, is indispensable to the establishment of the Department of Theatre Arts and subsequent introduction of courses in theatre management from diploma to Ph.D. levels. This is an extraordinary achievement made by the synergy and collaborative team-work efforts of the Ibadan veteran teachers and masters of theatre arts, who as trainers virtually trained the majority of past and present literary practitioners of theatre arts in Nigeria today. 
Geoffrey Axworthy was not a magician and did not achieve the noble feats of the Ibadan School of Drama all alone. He was strongly assisted and supported by a group of other equally dedicated theatre and cultural artists, both foreigners and locals, including Martin Banham, Dapo Adelugba, Kalu Uka, Dexter Lindesay, Wole Soyinka, Jide Malomo, Olu Akomolafe, Ola Rotimmi and Dr. Joel Adedeji who became the first head of Department of Theatre Arts, University of Ibadan. These scholars built a foremost and formidable arts and cultural academic department of the theatre discipline in a foremost university in Africa by giving themselves and their best. The department housed every unit of the theatre discipline and gave the various units their most insightful theoretical and practical eclectic and valued representations, so much so that foreigners far and wide including expatriates like Martin Banham, Clive Wake, Dexter Lindesay, and many others were attracted by the popularity and excellence of their programs' records.

In contemporary 2021 Nigeria, theatre arts and theatre management courses have become highly proliferated, with theatre management being taught and given a critical level of interest and attention in almost every department. In the theatre arts department of the University of Benin alone, between retired Professor M.P. Awodiya and my humble self, we have successfully trained and graduated about 3000 students between 1980 to 2017 and 1989 till date respectively between us. Students who have been grilled in the `nitty gritty` of the universality and indispensability of the principles of management to every organization and organized cooperative public and private enterprise generally, as well as their specific applications to the intricate fundamental processes of the theatre as unique art and business.

\section{Methodology OF THE STUdy AND DEMOgRAPHIC CHARACTERISTICS OF THE RESPONDENTS}

The study utilized the survey method in acquiring primary data as well as library and internet sources for secondary literary information. The study was conducted in University of Benin, in the department of Theatre Arts. The study was targeted to those who have the capacity to understand the promiscuous behaviors and tendencies of female undergraduate university students interrogated in the study. It includes hall mistresses, wardens and porters, security officials at entrance gates, female sundry items shop keepers and retailers, radio/television correspondents/reporters, guidance counselors of the university, female hair salon stylists and beauticians, lorry, tipper and trailer drivers, matured/seasoned social commentators/informants on general affairs, and lastly, select devoted and diligent Christian fellowship group leaders in Ekehuan and Ugbowo campuses of the University of Benin. Applying a cross-sectional descriptive study technique, the multi-stage/multi-dimensional sampling technique was used in selecting two hundred and fifty persons from the aforementioned categories and groups who constituted the study community or population. It was carried out during the 2017/18 academic session, between the months of July, August, September, October, November and December (6 months).Within the 6-months period, a total of one thousand, five hundred questionnaires were developed according with Beliefs and Actions Scale (SABAS) measuring device, and was used as baseline and end line data collection. At the baseline, the SABAS survey tool comprising thirty variables based on promiscuity (10), pregnancy (10), and abortion (10) was qualitatively and quantitatively analyzed. The recovered questionnaires (1500) were subjected to random-selection picking 
from which 250 questionnaires representing $100 \%$ of the baseline total figure was recovered. For the end-line process, the 250 selected original questionnaires were then scrutinized for accuracy of completion and quality/validity of the responses provided by the respondents. At this stage, fifty of the questionnaires fell short either due to illegibility, choosing more than one option, or having blank options which made generalizations on the variable inconclusive in percentage terms, and indicating a response rate of questionnaires returned of $80 \%$. Response categories for the SABAS were deployed on a Likert scale structure ranging from "Strongly Agree" to "Strongly Disagree" with a corresponding value ranging from 1-5. The SPSS Version 15 statistical software was used in carrying out all data analysis qualitatively and quantitatively as earlier stated. Frequency tables and cross-tabulations were statistically computed. For accuracy, reliability and record purposes, the objectives of the investigation were explained to all the participants who demonstrated more than average fluency in the language (English) in which the study was carried out. To encourage free and flexible responses, confidentiality in terms of anonymity of their identity was guaranteed to the respondents. They willingly gave their consent to participating in the exercise without any coercion.

The basic criteria for selecting respondents who were engaged in the study mentioned that they could have whatever profession, position or vocation that recommended the individual or group for participating, for a period not less than five years and secondly demonstrating clear knowledge and insights of the constructs and variables that were considered. Every of the initial $250(100 \%)$ and $200(80 \%)$ finally selected respondents that participated in this study were thus selected. The respondents (as mentioned earlier in the top section of the methodology description) are from various social groups and range from 17 to 25 years (mainly students); and 30 to 65 years (being individuals in the professional and vocational cadres). Representatives of both genders were involved in the study. Yet, emphasis was given to women at some points and to men at other points, depending on the nature and sensitivity of the subject-item under investigation. In the final analysis, the total involvement of students and non-students stood at $60 \%$ to $40 \%$ being 120 students and 80 non-students respectively. Furthermore, the ratio of female to male students in the students' category is 80 females to 40 males or $100 \%$ and $50 \%$ respectively. Similarly, the ratio of female to male in the non-student category is $70 \%$ to $30 \%$, or 55 females and 25 males respectively. The distribution of female and male in the study tilts in favor of women who are deemed to be more sensitive and understanding of the core issues of promiscuity, prostitution, pregnancy and abortion surveyed in the research. With regards to educational qualification, the criterion applied in determining qualification for engaging in the study was the O'Level which made holders of the WAEC, NECO, IJMB and NABTEB to be the minimum level of educational level of those who participated in the study. About $50 \%$ or 40 respondents in the non-student category possessed master and doctorate degrees, which should have impacted upon the quality of their responses. With regard to the religious affiliations and inclinations, about $70 \%$ or 140 of the respondents across board were Christians, about $25 \%$ were Muslims and only about $5 \%$ were flexible. Furthermore, since the economic and financial conditions or situations of individuals can affect their dispositions, inclinations and perceptions of intricate and sensitive behavioral issues, only people who are employed and above grade level 9, who earned a minimum monthly remuneration of 100,000 and not less than 1.2 million naira, or equivalent annually, were eligible to participate in the study. 


\section{PRESENTATION AND DiscUSSION OF RESUlts (FINDINGS) OF THE STUDY}

\subsection{Profile on Promiscuity (Prostitution)}

The study utilized the SABAS survey tool to measure three negative female vices alongside their debilitating impacts on educational theatre management training and practice (1) nature and rate of promiscuity (prostitution), (2) nature and rate of pregnancy, and (3) nature and rate of abortion. On profile or stereotype (1), in terms of meaning, promiscuity is defined or perceived as the tendency of females to manifest indiscriminate and unrestricted sexual tendencies, especially by having or being willing to have sex with multiple partners, and for financial or material rewards or favors (Divine Otobor, Law Notes; 2018: 26). Promiscuity of females is disturbing and worrisome at any age, but more in relation to females of younger age groups, especially between the ages of 15 to 25. As it is obvious from the tables on this category, the aggregate of responses show a prevalence of strongly agree and agree totaling to about $70 \%$ or 140 respondents of the population of the study, which indicate a positive affirmation of the postulate that many female theatre students are given to promiscuity or prostitution. The dissenting voices are feeble and represent only 40 respondents, or $20 \%$ of the population, with a meager $5 \%$ being unsure or undecided, or part of the dissenting voices. In fact, more than $2 / 3$ rd of the study population of 200 , totaling 160 respondents or $80 \%$, believed that theatre arts as a course by nature encourages female students to be promiscuous. They expressed the conviction that the unavoidable intimacy and passions aroused during intimate roleplaying was a very strong factor that promotes promiscuity amongst female theatre undergraduates who are kissed, necked, fondled and who sometimes are technically openly sexual on stage before the audience. In addition, a majority above $70 \%$ of the respondents believed that most theatre female undergraduates are ravishingly beautiful, wear exotic makeups, make resplendent hair-styles, and wear very skimpy, seductive and unraveling blouses or tie-wraps that reveal well-rounded oiled breasts. Furthermore, they wear tightly hugging miniskirts and waist wraps which encircle their swaggering buttocks, display beautiful waists adorned with scintillating and titillating beads, expose mesmerizing oiled thighs, parade polished well-manicured fingers and nails, wear shimmering wrist bands, display tantalizing ankle adornments and tattoos, and often perform with passionate and electrifying dexterity. Moreover, they exhibit tremendous skill, grace and grandeur in especially 'down to kill mesmerizing dances' that never fail in 'missing the target' of inducing uncontrollable sexual feelings in hot-blooded men in an audience, men who barely wait for the stage performance to end, before responding to the carefully-packaged, calculated, premeditated and well-delivered open sexual invitations and lustful messages (Interview; Mrs Ndikanma: 2020). The respondents revealed in addition that the majority of the female theatre undergraduates were indiscriminate in dealing with men, not regarding their ages, marital status, or even social status, and that the major factor of a man's eligibility for their patronage is the possession of cash. The popular parlance that expresses this in Nigeria is 'money for hand; back na ground' (Interview, Mrs Ijomone: 2020). Mrs Ijomone further informed that the main reason for their promiscuity is to obtain some money to augment the low pocket money they receive from parents and guardians and to be able to afford big phones, refrigerators, rugs, and so forth, which are induced by peer pressure and belonging to the 'big girls on campus league'. Incidentally, the views expressed by the interviewees above were further corroborated by a majority or $75 \%$ and $83 \%$ of the respondents respectively; thus establishing their genuineness and validity. On a final note, the respondents placed the blame of the theatre 
management students on them, thus absolving their parents, family and government of complicity and responsibility, which is not quite acceptable to the researcher. Similarly, the respondents also placed the blame of poor enrolment on the female students whom they allege discourage potential students through their outrageous negative sexual behaviors.

\subsection{Profile on Pregnancy}

In profile or stereotype (2) we investigate the nature and rate of pregnancy. Pregnancy is defined and perceived as the state or condition of conception or being conceived of a female. More specifically, Igbunuoghene Saint, $(2019,16)$ explains pregnancy as a state wherein a developing embryo, fetus or unborn offering is planted or contained in the womb or within the body of a woman prenatally. In the Nigerian context and parlance, pregnancy simply refers to and describes a woman 'carrying belle'. Usually challenges and problems arise when the source (father) of the belle is not known and the immediate condition or situation of the woman carrying the belle are not conducive due to timing, health and other social, economic, religious and 'educational' complications. Pregnancy of females is usually a phenomenon accompanied with joy when the conditions surrounding the pregnancy are normal, healthy and positive. However, when the conditions are not conducive, pregnancy can become very disturbing and problematic, especially with girls of younger ages and who are out of wedlock as well as receiving formal educational training. Thus pregnancy is unwanted and they are unprepared for it. Incidentally, promiscuity and pregnancy are closer than Siamese twins and are in fact almost like conjoined twins who are glued together and have to be separated, thus wherever promiscuity is present or rife, pregnancy is almost also invariably and unavoidably present. Furthermore, in truth, pregnancy can be 'embarrassing' to a female of any age or status, as long as it is not wanted and therefore not prepared for. Even a married woman who seriously needs a child may be forced to abort pregnancy if she is not properly pregnant in the first place or prepared for the baby. As it is obvious from the tables on this category, the aggregate of responses show a prevalence of strongly agree and agree totaling to about $72.06 \%$ or 145 respondents of the population of the study, which indicate a positive affirmation of the postulate that many female theatre students are given to early and unwanted pregnancies. The dissenting voices are feeble and represent only $26.0 \%$ or 52 of the respondents. In fact, more than $2 / 3 \mathrm{rd}$ of the study population of 200 , totaling 150 respondents or $75 \%$, believed that theatre arts as a course by nature encourages students to be promiscuous and therefore consequently to be pregnant. They were convinced that the unavoidable intimacy and passions aroused during intimate roleplaying was a very strong factor that promotes post production sex amongst female theatre undergraduates who are impregnated in the process. The study revealed that the fundamental reasons or factors underlying the avoidable pregnancies are: (a) having hurried, heated and spontaneous sex which leads to ignoring or forgetting to use contraceptives and other pregnancy prevention aids, (b) such spontaneous, forceful and passionate sex can result in destruction of pregnancy prevention aids (even when of good quality) in the process, thus resulting in unwanted pregnancy, (c) insisting on 'natural-skin-touch-smoothness' feeling, mostly by males, with ladies throwing caution to the winds and indiscriminately compromising, cooperating and yielding along, even when they know very well the implications and usual outcome of such risky demands and insistence by the male partner or partners at the end of the day. Another factor that contributed to and increased pregnancy amongst female theatre students derived from the study is competition or competitiveness. 
The girls just want to outdo or excel each other on who had the most pregnancies, or just who was more fertile, and correspondingly who procured the most abortions in the duration of the program, amongst a particular class or set of students. This view was held and supported by as many as 136 or $68 \%$ of the respondents who strongly agreed as well as disagreed. Furthermore, the view that theatre arts female undergraduate students lacked adequate sexual and reproductive health enlightenment was supported by 124 or $62 \%$ of the respondents, which accounts for or explains why the rate of pregnancy is very high. On the other hand, the evil scourges of rape and cultism were identified as fuelling unplanned pregnancies. Rapists according to the study are responsible for about $10 \%$ to $20 \%$ of unwanted pregnancies, which invariably lead to abortions. Furthermore, male and female cultists under hypnotic spell of charms, drugs and so forth engage in indiscriminate sex under possession, which results in unwanted pregnancies. Other factors identified as aiding unwanted pregnancies are the lack of knowledge of 'safe period' and fear of or non-use of contraceptives. Lack of exposure due to excessive 'parental' restriction of teenagers was identified as intensifying the urge of such girls to explore/experiment with sex and pregnancy and abortion. Lack of knowledge of how pregnancy occurs usually leads to using the not so reliable 'Withdrawal method' which is also a known source of unwanted pregnancies (OkpeIdjerhe, Ughelli North LGA Quarterly Health Talks, 2019). A majority of the respondents are of the opinion that unmarried undergraduate students who experience unplanned pregnancy are stigmatized and discriminated against and sometimes parents, guardians, family and friends tend to withdraw support and in some cases abandon them.

\subsection{Profile on Abortion}

The last stereotype or profile of negative behavioral manifestation of female theatre undergraduate students (3) investigated is the nature and rate of abortions committed by them. Abortion according to Norris et al., (2011, 50-52), Berry-Bibee et al. (2015), Okonofua (2013) and Ngwu (2016, 177-180) is defined variously and explained as the premature or untimely elimination/termination of a pregnancy through surgical means or otherwise, thus resulting in the death of the embryo or fetus. Abortion is illegal in Nigeria and the study revealed that abortion-related complications, morbidity and mortality rates in the country are very high and worrisome. A recent research source estimates that about 500,000 unsafe abortions are carried out in Nigeria every year resulting in spiraling morbidity and mortality. The study categorically reveals that due to ignorance of what to do or where to go to seek help, many university pregnant undergraduates, including those focused upon in this study, usually delay and procure abortions when it is getting late, usually between four and six months. Thus abortions are carried out at a rather risky stage which often results in complications ending in death or permanent damage to the reproductive system. Furthermore, the study revealed a very high level of stigmatization against victims of abortion (144 respondents equivalent to $72 \%$ of the Sampled Study Population, (SSP), observed in family, educational environment and general society circles on cultural, legal and religious grounds or fronts). Sixty eight percent or 136 respondents were of the deep conviction that females who committed abortion have 'killed' and committed sin and thereby deserve to die because the wages of sin is death. Since the female did not get pregnant alone, this would tantamount to a great injustice if her male counterpart is left of the hook, in places/cases where abortion victims are summarily executed or tortured. Ninety six respondents or 48 being almost half of the respondents equally strongly felt that a female who had committed abortion would certainly be a bad 
influence and is most likely to induce other innocent students to accept and to commit abortions. Similarly, 103 or $51.5 \%$ of the respondents were equally of the view that a female undergraduate who had committed abortion can never again enjoy optimum health and is most likely to have sick/weak children, including making her husband sick/weak. Moreover, $62.5 \%$ of the respondents felt categorically that a female undergraduate who committed abortion while in school can never again be morally trusted and is most likely to be sexually loose and given to perversions. In much the same vein, $60 \%$ of the respondents strongly felt that a female who had committed abortion can never be a good and stable mother and may influence her female children negatively. Furthermore, a majority of the respondents being 166 , (or $83 \%$ ) very strongly believed that a female undergraduate who committed abortion in her early age, especially multiple abortions, is most likely to have damaged her womb and therefore unlikely to be able to 'produce healthy balanced' children who can live long and excel in life generally. In another dimension, $68 \%$ or 136 of the respondents felt strongly that parents should be made to share the blame and punishment of a girl who commits abortion, especially the mother, which emphasizes the educational and socialization roles of parents.

\section{CONCLUSION AND RECOMMENDATIONS}

Promiscuity, pregnancy and abortions are not only neither falsely speculated, but actually rife and rampant negative female undergraduate immoral behaviors that have eaten deep into the fabric of educational theatre management training institutions and programs in Nigeria, with very deep and severe impacts on various manifestations and ramifications as enumerated and discussed in this study. Furthermore, these vices no doubt have negative impacts upon the trainers, the trainees especially, the family and the society. Unwanted pregnancies and abortions are the consequences of poor sexual and reproductive health knowledge dissemination, especially in any morally debased society and depraved people where the appropriate roles of parents and social institutions such as the family, school, church and government have not been properly implemented. The current reality is that unsafe abortion poses a huge challenge to female undergraduate's health and reproductive lives in Nigeria where abortion is still ranked and judicially regarded as illegal and a punishable crime. The result is that about 500 abortions are carried out annually in Nigeria with about $70 \%$ of them being carried out surreptitiously in clandestine conditions marked with unhygienic conditions as well as inadequately qualified medical personnel and equipment/ facilities, with only about $30 \%$ being implemented in optimum conditions (Norris et al, 2011, 50-52), Berry-Bibee et al. (2015), Okonofua (2013) and Ngwu (2016, 177-180). On the other hand, the World Health Organization Report (2012) estimates that 97\% of abortion procedures in Africa are performed unsafely either by an unskilled provider, with inadequate methods or in an unhygienic environment. The poor practice of a safe and common medical procedure thus results in the death of more than 26,000 African women each year. By every consideration, this situation is clearly neither palatable nor acceptable and therefore all stakeholders who are connected with it must work conscientiously to tackle it in order to change the narrative and thereby save its negative impacts upon educational theatre management training institutions' performance and practice in particular, and the well-being, health and general roles fulfillment of females in the Nigerian society in general. Passing and trading blames has never and will never solve any problems, hence the following recommendations towards the way forward. 
First and foremost, the Nigerian government, especially at the federal level, which has in recent decades perceived and interpreted appointment or involvement in governance only from the perspective of self-benefaction and enrichment with public fiscal and financial resources, must have rethink and positive change of mind. This view of governance has resulted in people in government embezzling and looting unto themselves and their immediate families the abundant resources of the nation, thereby leaving the nation and Nigerians hollow, shallow, disempowered, disenchanted, hopeless, miserably, unimaginably and unbearably poor, unemployed, hungry and deprived of all access to comfortable and human living conditions. This is the genesis of promiscuity and prostitution, which results in pregnancy and subsequent abortion, and is equally the 'birth' as well as sustainer of corruption, unemployment, as well as lack of adequate amenities, facilities and infrastructure at all levels. That does not exclude all manners of deadly and evil crimes and insecurity that dominate contemporary Nigeria. A thieving and self-serving government, that compromises its core responsibilities in all ramifications, is definitely an evil wind that cannot blow any positive appurtenances of life to anyone, but itself and its immediate family and possibly friends who have always represented a tiny minority of Nigeria's masses of about 200 million quite deprived people. This has been the bane of the economic, financial and general underdevelopment of the country and will remain so until the people take their destiny into their own hands to change it by themselves and for themselves, or the almighty God they call upon, albeit not diligently, generously and benevolently changes the trend and liberates the country from the shackles of its oppressing and repressing minority. This is the truth and nothing but the truth.

However, at the human level presently, in order to cushion and alleviate the problems engaged in this study as well as their immediate and long-term impacts, the following further recommendations are pertinent and expedient:

1. There is a strong need to establish structures such as STUDENTS' SUPPORT SERVICES that would promote mutual interdependency, understanding and supportive backing amongst students in academic, moral, physical, sexual and reproductive health concerns, issues, and so forth. Thus students can care and share formally and positively in various situations when they may have need or find themselves with one another.

2. Communication Media Broadcast TV/Radio service operations, such as the ones available in UNIBADAN, should be made available on all campuses for regular dissemination of relevant information or correspondence for the general well-being of all students, either in terms of giving out or receiving.

3. Government, parents, guardians and families should endeavor to provide basic and essential needs of their children (students) in tertiary institutions, especially the female students, so as not to push them into promiscuity and consequent problems of pregnancy and abortion.

4. Since pregnancy and abortion are natural offshoots of normal intimate adult relationship which is basically not illegal, the abortion law should be abandoned in Nigeria so that students who fall victim can share their experiences without repression, and access campus abortion support services. This would remove the physical and psychological complications and traumas under the present system to the barest minimum. In other words, abortion should be legalized or made legitimate. 
5. Prophylactic counseling leading to early detection and prevention of health disorders are usually more profitable than the most sophisticated treatment systems or procedures. Accordingly, every university should establish STUDENTS' WATCH OUT CENTRES (OR UNITS), in Guidance and Counseling departments of universities, which can also be established as integral units of SUG, towards promoting and facilitating early detection and rehabilitation of students with problems of promiscuity and pregnancy symptoms, in order to prevent them from escalating to cases for abortions.

6. Far reaching security measures should be provided to floodlight dark areas that provide canopy for illicit night love affairs. Classrooms and open spaces should either be well-lit or monitored, and so forth, to reduce environment that promotes promiscuity, cultism, rape, etc.

7. Government and management of universities in Nigeria should intensify information and action aimed at reducing discriminating and stigmatizing of pregnant students and students who had abortions to the barest minimum. Such students should be saved from avoidable further suffering and trauma which can result in morbidity, mortality, psychosis or full blown lunacy.

8. Further research should be carried out by specialists from different fields using the data and information provided by this research as baseline to extend the frontiers, and abundant information on the vices of promiscuity (prostitution), pregnancy and abortion. This research was mainly intended at affirming or refuting the widespread speculations/allegations that a majority of undergraduate female theatre management students are highly promiscuous and therefore experience unwanted pregnancies and undergo abortions, as well as some of the major impacts/risks associated with the aforementioned negative behaviors. The present research is undoubtedly expected to assist in improving the moral academic and managerial framework of educational theatre programs in Nigeria. However, subsequent researches are required to measure and determine the exact effects of their promiscuity and attendant pregnancies/abortions on their academic, mental, physical and spiritual well-being, future roles as wives, mothers, and ambassadors of families, society and so forth, and the possible negative effects/impacts of their negative behaviors upon educational systems in Nigeria in general, and educational theatre management training programs and practice in particular. 


\section{Data Obtained in this Field of Investigation:}

Table 1 Perception of the Respondents on Promiscuity (Prostitution) between January and June, 2019.

\begin{tabular}{|c|c|c|c|}
\hline & Response & Frequency & Percentage \\
\hline \multirow{5}{*}{$\begin{array}{l}\text { Do you agree with a definition of promiscuity as a tendency of } \\
\text { persons to manifest characteristics of indiscriminate and } \\
\text { unrestricted sex, and therefore a form of sexual disorder or } \\
\text { indiscipline? }\end{array}$} & Strongly agree & 140 & 70 \\
\hline & Agree & 30 & 15 \\
\hline & Unsure & 08 & 04 \\
\hline & Disagree & 14 & 07 \\
\hline & Strongly disagree & 08 & 04 \\
\hline \multirow{5}{*}{$\begin{array}{l}\text { An unmarried undergraduate female theatre management student } \\
\text { having boyfriends including her classmates and men-friends, some } \\
\text { of whom are more than twice her age and having indiscriminate } \\
\text { sex with her multiple partners, especially under financial } \\
\text { consideration or inducement is promiscuous }\end{array}$} & Strongly agree & 120 & 60 \\
\hline & Agree & 40 & 20 \\
\hline & Unsure & 10 & 05 \\
\hline & Disagree & 20 & 10 \\
\hline & Strongly disagree & 10 & 05 \\
\hline \multirow{5}{*}{$\begin{array}{l}\text { To the best of your knowledge, do undergraduate female theatre } \\
\text { management students fit into the category just described above, in } \\
\text { other words; do you know, feel, or believe that they are } \\
\text { promiscuous? }\end{array}$} & Strongly agree & 118 & 59 \\
\hline & Agree & 40 & 20 \\
\hline & Unsure & 10 & 05 \\
\hline & Disagree & 18 & 09 \\
\hline & Strongly disagree & 14 & 07 \\
\hline \multirow{5}{*}{$\begin{array}{l}\text { In other words, you accept or agree and do not feel that it is wrong } \\
\text { to classify or regard undergraduate female theatre management } \\
\text { students as being promiscuous or pseudo prostitutes? }\end{array}$} & Strongly agree & 130 & 65 \\
\hline & Agree & 50 & 25 \\
\hline & Unsure & 08 & 04 \\
\hline & Disagree & 08 & 04 \\
\hline & Strongly disagree & 04 & 02 \\
\hline \multirow{5}{*}{$\begin{array}{l}\text { Going further, do you consider and agree or feel that the tendency } \\
\text { of undergraduate female theatre students to be promiscuous has a } \\
\text { strong association or relationship with the very nature of the } \\
\text { course they are studying? }\end{array}$} & Strongly agree & 110 & 55 \\
\hline & Agree & 50 & 25 \\
\hline & Unsure & 10 & 05 \\
\hline & Disagree & 20 & 10 \\
\hline & Strongly disagree & 10 & 05 \\
\hline \multirow{5}{*}{$\begin{array}{l}\text { Could it be that the intimate love scenes which promote } \\
\text { unavoidable body contact, sometimes involving kissing, necking, } \\
\text { hugging, and so forth can arouse the heat of sexual passion } \\
\text { uncontrollably, thus promoting promiscuity of the students? }\end{array}$} & Strongly agree & 120 & 60 \\
\hline & Agree & 30 & 15 \\
\hline & Unsure & 08 & 04 \\
\hline & Disagree & 20 & 10 \\
\hline & Strongly disagree & 22 & 11 \\
\hline \multirow{5}{*}{$\begin{array}{l}\text { Do you agree with the opinion that undergraduate female educational } \\
\text { theatre management students are usually very pretty or ravishingly } \\
\text { beautiful, dress very seductively and reveal their bodies a lot while } \\
\text { acting, or even dancing or singing; which can arouse themselves, their } \\
\text { male counterparts, as well as other hot-blooded men in the audience, } \\
\text { which can promote promiscuity of these girls? }\end{array}$} & Strongly agree & 120 & 60 \\
\hline & Agree & 32 & 16 \\
\hline & Unsure & 12 & 06 \\
\hline & Disagree & 22 & 11 \\
\hline & Strongly disagree & 14 & 0.7 \\
\hline \multirow{5}{*}{$\begin{array}{l}\text { Are you aware and do you agree that undergraduate female } \\
\text { educational theatre management students usually date multiple } \\
\text { men, regardless of their ages or educational status, mainly for } \\
\text { financial reasons or material gratification, above artistic and moral } \\
\text { considerations? }\end{array}$} & Strongly agree & 96 & 48 \\
\hline & Agree & 48 & 24 \\
\hline & Unsure & 14 & 07 \\
\hline & Disagree & 32 & 16 \\
\hline & Strongly disagree & 10 & 05 \\
\hline \multirow{5}{*}{$\begin{array}{l}\text { Are the government, family, parents and society free from blame } \\
\text { and should only the undergraduate female educational theatre } \\
\text { management students be blamed for their promiscuity in Nigeria? }\end{array}$} & Strongly agree & 90 & 45 \\
\hline & Agree & 48 & 24 \\
\hline & Unsure & 16 & 08 \\
\hline & Disagree & 24 & 12 \\
\hline & Strongly disagree & 22 & 11 \\
\hline \multirow{5}{*}{$\begin{array}{l}\text { Is it true that undergraduate female educational theatre } \\
\text { management students can and are actually discouraging potential } \\
\text { students by their promiscuity and are thus liable for dwindling } \\
\text { students' enrolment in educational theatre management programs? }\end{array}$} & Strongly agree & 90 & 45 \\
\hline & Agree & 36 & 18 \\
\hline & Unsure & 24 & 12 \\
\hline & Disagree & 16 & 08 \\
\hline & Strongly disagree & 34 & 17 \\
\hline
\end{tabular}


Table 2 Perception of the Respondents on Pregnancy between January and June, 2019.

\begin{tabular}{|c|c|c|c|}
\hline & Response & Frequency & Percentage \\
\hline \multirow{5}{*}{$\begin{array}{l}\text { Do you agree with the view that pregnancy is a condition in which } \\
\text { a female is impregnated though sex by planting an embryo or } \\
\text { foetus in her womb or body; or in other words, to put a female in } \\
\text { a family way towards having a child? }\end{array}$} & Strongly agree & 140 & 70 \\
\hline & Agree & 30 & 15 \\
\hline & Unsure & 10 & 05 \\
\hline & Disagree & 12 & 06 \\
\hline & Strongly disagree & 08 & 04 \\
\hline \multirow{5}{*}{$\begin{array}{l}\text { Are you aware and do you agree that undergraduate female } \\
\text { educational theatre management students mostly get pregnant } \\
\text { during their course of study due to a high level of promiscuity? }\end{array}$} & Strongly agree & 120 & 60 \\
\hline & Agree & 42 & 21 \\
\hline & Unsure & 10 & 05 \\
\hline & Disagree & 20 & 10 \\
\hline & Strongly disagree & 08 & 04 \\
\hline \multirow{5}{*}{$\begin{array}{l}\text { Do you agree and therefore support the view that undergraduate } \\
\text { female educational theatre management students usually have a } \\
\text { high and alarming rate of pregnancy due to deliberate refusal to } \\
\text { utilize available and affordable contraceptives? }\end{array}$} & Strongly agree & 110 & 55 \\
\hline & Agree & 38 & 19 \\
\hline & Unsure & 12 & 06 \\
\hline & Disagree & 14 & 07 \\
\hline & Strongly Disagree & 26 & 13 \\
\hline \multirow{5}{*}{$\begin{array}{l}\text { Do you agree that undergraduate female educational theatre } \\
\text { management students who get pregnant in the course of their } \\
\text { programs suffer untold and indescribable complications in their } \\
\text { programs, extending into other hazards in their future life? }\end{array}$} & Strongly agree & 94 & 47 \\
\hline & Agree & 42 & 21 \\
\hline & Unsure & 18 & 09 \\
\hline & Disagree & 16 & 08 \\
\hline & Strongly disagree & 30 & 15 \\
\hline \multirow{5}{*}{$\begin{array}{l}\text { Are you aware and do you agree that undergraduate female } \\
\text { educational theatre management students in their majority have } \\
\text { unwanted babies for which they are not prepared, thereby causing } \\
\text { them embarrassment, shame and disgrace which usually outlives } \\
\text { the program? }\end{array}$} & Strongly agree & 118 & 59 \\
\hline & agree & 42 & 21 \\
\hline & Unsure & 12 & 06 \\
\hline & Disagree & 20 & 10 \\
\hline & Strongly disagree & 08 & 04 \\
\hline \multirow{5}{*}{$\begin{array}{l}\text { Due to the temptations provoked by intimacy that undergraduate } \\
\text { female educational theatre management students are exposed to, } \\
\text { which promotes their promiscuity, pregnancies and abortions, } \\
\text { parents, peers, society and the government should be empathic and } \\
\text { sympathetic towards them; thus being more tolerant and } \\
\text { supportive of pregnancy and abortion victims! }\end{array}$} & Strongly agree & 14 & 07 \\
\hline & Agree & 22 & 11 \\
\hline & Unsure & 16 & 08 \\
\hline & Disagree & 42 & 21 \\
\hline & Strongly disagree & 106 & 53 \\
\hline \multirow{5}{*}{$\begin{array}{l}\text { Are you aware and do you agree that a majority of undergraduate } \\
\text { female educational theatre management students' pregnancies are } \\
\text { traceable to having unplanned, spontaneous and heated sex } \\
\text { episodes, which lead to their ignoring or forgetting to use } \\
\text { contraceptives? }\end{array}$} & Strongly agree & 106 & 53 \\
\hline & Agree & 44 & 22 \\
\hline & Unsure & 18 & 09 \\
\hline & Disagree & 10 & 05 \\
\hline & Strongly disagree & 22 & 11 \\
\hline \multirow{5}{*}{$\begin{array}{l}\text { Are you aware and do you agree that undergraduate female } \\
\text { educational theatre management students, even when they use } \\
\text { condoms (both parties), which may even be of high quality, can } \\
\text { get them destroyed in the process of boisterous and dexterous love } \\
\text { making, which thus results in pregnancy due to lack of careful and } \\
\text { tender use due to their heated passion }\end{array}$} & Strongly agree & 110 & 55 \\
\hline & Agree & 32 & 16 \\
\hline & Unsure & 20 & 10 \\
\hline & Disagree & 14 & 07 \\
\hline & Strongly disagree & 24 & 12 \\
\hline \multirow{5}{*}{$\begin{array}{l}\text { Male partners of undergraduate female educational theatre } \\
\text { management students, like many others usually demand for "skin } \\
\text { to skin touch, without condom,", which they feel is more } \\
\text { enjoyable and satisfying, and the females oblige without } \\
\text { considering the risks involved; including also the practice of } \\
\text { quick withdrawal method, all of which cause pregnancies! }\end{array}$} & Strongly agree & 100 & 50 \\
\hline & Agree & 32 & 16 \\
\hline & Unsure & 22 & 11 \\
\hline & Disagree & 28 & 14 \\
\hline & Strongly disagree & 18 & 09 \\
\hline \multirow{5}{*}{$\begin{array}{l}\text { Do you agree that undergraduate female educational theatre } \\
\text { management students lack adequate sexual and reproductive } \\
\text { health knowledge of safe periods, application of a variety of } \\
\text { contraceptives, and so forth; and should thus not be discriminated } \\
\text { against or stigmatized, but rather rehabilitated and supported for } \\
\text { quick recovery, especially after an abortion! }\end{array}$} & Strongly agree & 86 & 43 \\
\hline & Agree & 44 & 22 \\
\hline & Unsure & 24 & 12 \\
\hline & Disagree & 22 & 11 \\
\hline & Strongly disagree & 24 & 12 \\
\hline
\end{tabular}


Table 3 Perception of the Respondents on Pregnancy between January and June, 2019.

\begin{tabular}{|c|c|c|c|}
\hline & Response & Frequency & Percentage \\
\hline \multirow{5}{*}{$\begin{array}{l}\text { Do you agree with the definition and meaning that abortion entails } \\
\text { the premature or untimely elimination or evacuation of a } \\
\text { pregnancy through surgical or other process which results in the } \\
\text { premeditated death of the embryo or foetus; which is actually an } \\
\text { unborn baby or human life? }\end{array}$} & Strongly agree & 146 & 73 \\
\hline & Agree & 20 & 10 \\
\hline & Unsure & 08 & 04 \\
\hline & Disagree & 20 & 10 \\
\hline & Strongly disagree & 06 & 03 \\
\hline \multirow{5}{*}{$\begin{array}{l}\text { Abortion is illegal in Nigeria and therefore undergraduate female } \\
\text { educational theatre management students who willfully commit } \\
\text { abortions have violated the law and murdered a living soul; they } \\
\text { should thus be tried and sent summarily to jail! }\end{array}$} & Strongly agree & 96 & 48 \\
\hline & Agree & 42 & 21 \\
\hline & Unsure & 18 & 09 \\
\hline & Disagree & 20 & 10 \\
\hline & Strongly disagree & 24 & 12 \\
\hline \multirow{5}{*}{$\begin{array}{l}\text { Abortion is a sin; therefore undergraduate female educational } \\
\text { theatre management students who deliberately commit abortion } \\
\text { have sinned and are liable to go to hell, for the soul that sins shall } \\
\text { die. }\end{array}$} & Strongly agree & 88 & 44 \\
\hline & Agree & 46 & 23 \\
\hline & Unsure & 22 & 11 \\
\hline & Disagree & 14 & 07 \\
\hline & Strongly disagree & 30 & 15 \\
\hline \multirow{5}{*}{$\begin{array}{l}\text { Many undergraduate female educational theatre management } \\
\text { students who commit abortion lack access to appropriate } \\
\text { counseling facilities/opportunities. They do not know early } \\
\text { enough when they are pregnant and do not know how to handle } \\
\text { the situation, thereby resorting to committing abortion at advanced } \\
\text { stages of between } 4 \text { to six months }\end{array}$} & Strongly agree & 116 & 58 \\
\hline & Agree & 22 & 11 \\
\hline & Unsure & 20 & 10 \\
\hline & Disagree & 14 & 07 \\
\hline & Strongly disagree & 28 & 14 \\
\hline \multirow{5}{*}{$\begin{array}{l}\text { Abortions generally committed at advanced stages of pregnancy } \\
\text { are often complicated, more often resulting in death or permanent } \\
\text { damage to the reproductive system of the female with usually very } \\
\text { debilitating impacts, and should thus either be done early or } \\
\text { avoided. }\end{array}$} & Strongly agree & 102 & 51 \\
\hline & Agree & 47 & 23.5 \\
\hline & Unsure & 21 & 10.5 \\
\hline & Disagree & 20 & 10 \\
\hline & Strongly disagree & 10 & 05 \\
\hline \multirow{5}{*}{$\begin{array}{l}\text { Stigmatization refers to discrimination, hatred and withdrawal of } \\
\text { friendship or support from a female who had abortion. This } \\
\text { practice exhibited by parents, family and society is very negative } \\
\text { and counter-productive and should be stopped because it does not } \\
\text { provide good results. }\end{array}$} & Strongly agree & 88 & 44 \\
\hline & Agree & 46 & 23 \\
\hline & Unsure & 13 & 06.5 \\
\hline & Disagree & 24 & 12 \\
\hline & Strongly disagree & 29 & 14.5 \\
\hline \multirow{5}{*}{$\begin{array}{l}\text { Since it is not possible for undergraduate female educational } \\
\text { theatre management students or any female for that matter to get } \\
\text { pregnant alone, male partners should be involved in whatever is } \\
\text { done to the female to make them liable and to serve as check and } \\
\text { balance against "experimental excesses" that escalate } \\
\text { pregnancies and consequent abortions. }\end{array}$} & Strongly agree & 68 & 34 \\
\hline & Agree & 44 & 22 \\
\hline & Unsure & 28 & 14 \\
\hline & Disagree & 42 & 21 \\
\hline & Strongly disagree & 38 & 19 \\
\hline Is it true that undergraduate female educational theatre & Strongly agree & 111 & 55.5 \\
\hline management students who have committed abortion are a threat to & Agree & 40 & 20 \\
\hline other decent innocent girls and may contaminate or defile them? & Unsure & 16 & 08 \\
\hline Those who have committed abortion can no longer be trusted and & Disagree & 31 & 15.5 \\
\hline $\begin{array}{l}\text { reliable wives, cannot certainly be good mothers in the future and } \\
\text { are most likely to be morally debased }\end{array}$ & Strongly disagree & 2 & 1 \\
\hline \multirow{5}{*}{$\begin{array}{l}\text { The future health and well-being of undergraduate female } \\
\text { educational theatre management students who commit abortion is } \\
\text { permanently impaired, they can never enjoy optimum health } \\
\text { again, which equally affects their children, and those who } \\
\text { committed multiple abortions may never be able to have children. }\end{array}$} & Strongly agree & 130 & 65 \\
\hline & Agree & 26 & 13 \\
\hline & Unsure & 14 & 07 \\
\hline & Disagree & 26 & 13 \\
\hline & Strongly disagree & 04 & 02 \\
\hline \multirow{5}{*}{$\begin{array}{l}\text { Abortion is due to lack of not receiving adequate sexual and } \\
\text { reproductive health knowledge, therefore parents, especially } \\
\text { mothers of girls who committed abortion should be made to share } \\
\text { in the blame, in order to encourage parents, family and society to } \\
\text { carry out their education and enlightenment roles properly. }\end{array}$} & Strongly agree & 90 & 45 \\
\hline & Agree & 46 & 23 \\
\hline & Unsure & 18 & 09 \\
\hline & Disagree & 22 & 11 \\
\hline & Strongly disagree & 24 & 12 \\
\hline
\end{tabular}


Acknowledgement: The author would like to thank Mrs. Ndikanma, Mrs. M.J. Ijomone, Mrs. Ochuko Okpe-Idjerhe and Mrs. Divine Otobor,for interviews in their homes or work places, between January and June 2018.

\section{REFERENCES}

Akre C., Chabloz, J.M., Belanger, R.E, Michaud, P.A., Suris, J.C., (2013), Unwanted Sexual experience among adolescents: Shedding light on the gray zone between consensual and non-consensual sex. International Journal of Adolescent Medicine and Health, 25(1): 69-74.

Ayakoromo, B. F. (ed.) (2015), Effective Cultural Administration in Nigeria: A Critical Source Book. (Discuss on stigmatization, labeling and relegation of theatre arts and artists in Nigeria), Krafts Book Ltd, Ibadan.

Berry-Bibee, E. N., Jean, C.J., Telemaque, Y., Nickerson, N., Jean-Louis, S., Lathrop. E., (2015), "Stigma surrounding illegal self-induced abortion in urban Haiti", International Journal of Gynaecology and Obstetrics, 131.

Edomi, O., (2019) "Restructuring and Resource Control of Nigeria: The way forward for the Niger Delta minorities" (unpublished speech given by Ovie Edomi at the Urhobo Colloquium held at Oghara, Delta State, May 5-7, 2019).

Norris, A., Bessett, D., Steinberg, J.R., Kavanaugh, M.L., Zordo, S. D., Becker D., (2011), “Abortion stigma: a reconceptualization of constituents, causes, and consequences", Women's Health Issues, May-Jun 21(3 Suppl):S49-54.

Ngwu, C.N. (2016), "A Study of Public Perception in Abortion in Igbo-Etiti Local Government Area of Enugu State", Nigerian Journal of Social Sciences, University of Nigeria Nsukka: pp.175-188.

Ogunbiyi, Y., (ed.), (1981),.Drama and Theatre in Nigeria: A Critical Source Book, Nigeria Magazine, Lagos.

Plato, (2019), The Republic, Books 1-10(1st Ed.), Samaira Book Publishers, 329A, GF, Niti Khaad I, Indirapuram, Ghaziabad, up - 201010

World Health Organization DoRHaR, (2012), Safe Abortion: Technical and Policy Guidance for Health Systems, second edition.

\section{ISTRAŽIVANJE ŽENSKE PROMISKUITETNOSTI IZ PERSPEKTIVE POZORIŠNOG MENADŽMENTA: UTICAJ TRUDNOĆE I ABORTUSA NA UNIVERZITETSKA OBRAZOVNA POZORIŠTA U NIGERIJI}

Ova studija istražuje uticaje promiskuiteta, trudnoće i abortusa studentkinja dodiplomskih studija na upravljanje obrazovnim pozorišnim programom Univerziteta u Beninu, sa implikacijama na opštu pozorišnu praksu, uključujući Muson i Nolivud, u Nigeriji. Rasprostranjene su spekulacije da su studentkinje pozorišnih dodiplomskih studija promiskuitetne i da su zbog toga vrlo sklone trudnoćama i pobačajima iz razloga ili faktora koji nisu potvrđeni istraživanjem. Barem u pozorištu Univerziteta u Beninu do sada nije sprovedena tako specifična opsežna studija na ovu temu. Ipak, mnoge studentkinje su žigosane i tretirane samo kao 'unižene žene i potencijalne prostitutke' i ne uživaju blagonaklonost, podršku, poštovanje i čast kao njihove kolege u društvenim, fundamentalnim i naukama o životnoj sredini, kao i drugim oblastima akademskih studija. Ako rigorozna akademska istraga dokaže suprotno, ovo bi bilo ravno velikoj šteti i nepravdi kojom se treba hitno pozabaviti. Da ne pominjemo neotkrivene negativne uticaje koje je problem mogao imati ili trenutno ima na pozorišnu obuku i praksu Nigeriji: otuda i ova istraga. Metodologija, subjekti proučavanja i uzorak studije pažljivo su i sistematski utvrđivani. Nalazi su uglavnom pozitivni u pogledu istraženog negativnog ponašanja. Otuda preporuke upućuju na mere usmerene na proveru $i$ svođenje ovih poroka $i$ njihovog uticaja na minimum, kao i na poboljšanje moralnog, akademskog i upravljačkog okvira obrazovnih pozorišnih programa u Nigeriji.

Ključne reči: ženski promiskuitet, trudnoća, pobačaj, pozorišni menadžment, univerzitetsko obrazovno pozorište 